\title{
МЕЂУНАРОДНИ КОНТЕКСТ ОСНИВАҢА СРПСКОГ НАРОДНОГ ЖЕНСКОГ САВЕЗА 1906. ГОДИНЕ
}

САЖЕТАК: У раду се анализира утицај међународних организација женског покрета на оснивање Срйской нарояноі женской савеза. Реч је о Ме-

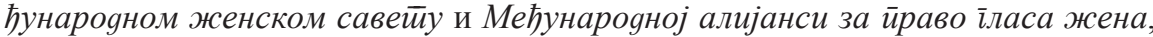
моћним организацијама које су путем снажног залагања подстицале стварање националних женских удружења у Европи, САД и Аустралији и њихово укључивање у женски покрет током прве деценије XX века. Циљ им је био укидање неравноправног приватно-правног, економског, друштвеног и политичког положаја жена и мушкараца. Мисија др Кете Ширмахер (Kaethe Schirmacher), која је као представница Међунарояне алијансе одржала предавање у Београ-

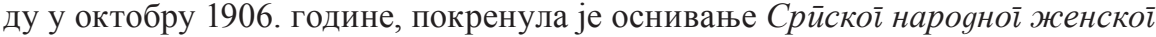
савеза, али и преиспитивање положаја жена у Краљевини Србији. Срйски савез објединио је рад добротворних хуманитарних женских организација у

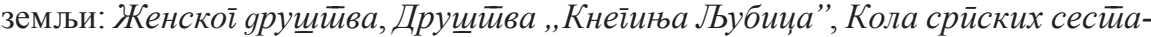

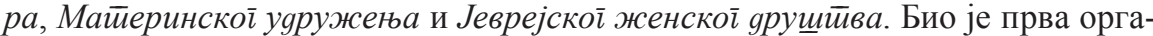
низација грађанског женског покрета у Краљевини Србији која је до Првог светског рата уобличила захтеве и предузела кораке ка измени одредаба у наследном и брачном праву, изједначавању професионалног положаја жена и мушкараца у државним службама и стицању политичких права.

КЉУЧНЕ РЕЧИ: Срйски нарояни женски савез, Међунароgна алијанса

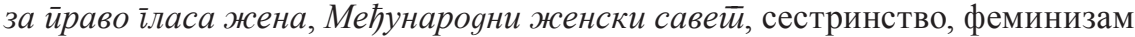

Појави међународних организација женског покрета претходила је потпуно нова културна појава - међународна преписка између жена различитог порекла, из различитих држава и друштава Западне Европе и Америке, која је деведесетих година XIX века припремила терен за изградњу утицајних политичких савеза. ${ }^{1}$ Посредством преписке постепено су уобличаване

${ }_{1}^{1}$ Politics and Friendship. Letters from the International Women Suffrage Alliance 1902-1942, Edited by Mineke Bosch with Annemarie Kloosterman, Columbus: Ohio State UP, 1990, 35. 
идеје, дефинисани су програми и стратегије за њихово остваривање у циљу укидања приватно-правне, друштвене, економске и политичке неравноправности жена и мушкараца. Успостављена је мрежа контаката између представница водећих европских националних удружења са америчким организацијама, размењиване су посете, књиге и штампани материјал. Иако прва међународна организација, Међунарояно уяружење жена (Association Internationale des Femmes), које су основале Францускиње у Женеви 1868. године, није била стабилна установа. Њено вођство успело је да сазове конгрес у Паризу у време одржавања Велике светске изложбе 1878. године. Скупу су присуствовале представнице из једанаест земаља. ${ }^{1}$ Након конгреса започето је ширење мреже међународног женског активизма, али и рад на истраживању друштвеног и економског положаја жена у Европи, којим је руководио Теодор Стентон (Theodor Stanton), син ангажоване америчке активисткиње Елизабет Кејди Стентон (Elizabeth Cady Stanton). Резултат је била прва обимна збирка ауторских текстова о покрету за еманципацију жена Женско йийање y Eвройu (The Woman Question in Europe. A series of original Essayes) која је објављена 1884. године. У њој је, осим Стентоновог рада о ситуацији у Француској, највише простора посвећено женском покрету у Енглеској, Немачкој, Холандији, Норвешкој, Шведској, Данској, Русији, Италији, Шпанији и Белгији. У посебном одељку о „Оријенту” објављени су текстови о Бугаркама, Јерменкама, Туркињама и Гркињама. ${ }^{2}$ Током осамдесетих година XIX века тежиште организованих активности жена помера се с француског на англоамеричко подручје. До тога је дошло зато што су у многим земљама Европе постојале законске препреке за слободно удруживање и за издаваштво којим руководе жене, али је значајну улогу одиграла снага и продорност протестантских представница борбе за женско право гласа и моралну реформу из Америке, Велике Британије и Северне Европе. ${ }^{3}$

Водеће представнице Америчкоі националноі удружења жена, Елизабет Кејди Стентон и Сузан Ентони (Susan Antony), на основу искуства које су стекле путујући по Европи иницирале су сазивање Међунароgног женскоі caвеӣa (International Council of Women, ICW) у Вашингтону 1888. године. Оснивачком конгресу присуствовало је највише Американки, али биле су заступљене и представнице из неколико европских земаља (Норвешке, Данске, Француске, Италије, Ирске, Енглеске). Савеш̄ је отворио врата за чланство различитим женским удружењима, од књижевних клубова до друштава за моралну чистоту и борбу против алкохолизма. Стремећи привлачењу

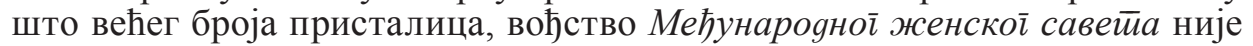
желело да се опредељује у вези са контроверзним питањима, а једно од њих било је и истицање захтева за право гласа жена. Када је на конгресу у Лондону 1899. године вођство и даље истрајавало на ставу да и противнице освајања политичких права жена заслужују да се чује њихово мишљење,

${ }^{1}$ Leila Rupp, Verta Taylor, "Forging Feminist Identity in an International Movement: A Collective Identity Approach to Twentieth/Century Feminism", Signs, Winter (1999), 366. Доступно на: https://www.journals.uchicago.edu/loi/signs?expanded=1999. Приступљено 24. 2. 2016.

${ }^{2}$ Karen Ofen, Evropski feminizmi 1700-1950. Politička istorija, Evoluta, Beograd 2016, 176-177.

${ }^{3}$ L. Rupp, V. Taylor, "Forging Feminist Identity in an International Movement", 367; K. Ofen, Evropski feminizmi 1700-1950, 177. 
група жена предвођена представницама из Немачке организовала је засебан састанак. На њему је одлучено да се оснује организација која ће се залагати искључиво за стицање политичких права жена, пре свега за право гласа. ${ }^{4}$ Убрзо је, после прелиминарног састанка у Вашингтону 1902. године, основана Међународна алијанса за йраво іласа жена (International Alliance for Women's Suffrage, IWSA) на конгресу у Берлину 1904. године. На челу седмочланог Извршног одбора била је председница Кери Чампан Кет (Carrie Champan Cat) из САД. У Алијанси је од оснивања обликован јак феминистички идентитет с јасним циљем постизања пуних грађанских, политичких и економских права жена. ${ }^{5}$ Упорно заступање става да су политичка права жена кључна за остварење правде у свету требало је да покаже да се Meђу-

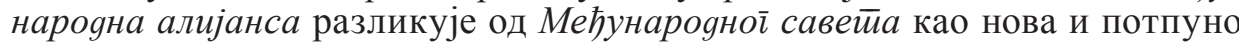
другачија међународна организација. ${ }^{6}$

Обе организације представљале су значајну политичку снагу међународног феминистичког покрета до почетка Првог светског рата. Под њиховим кровом развијана је антимилитаристичка и антиратна идеја која је водила ка стварању Међунарояноі комииетета жена за стиални мир, у Хагу 1915. године (International Committee of Women for Permanent Peace), односно Meちyнарояне женске лиіе за мир и слобоgу од 1919. године (Women's International League for Peace and Freedom)..$^{7}$ Осим ових организација, социјалисткиње предвођене Кларом Цеткин (Clara Zetkin) основале су Женску соиијалисииччку иниеернационалу 1907. године. Цеткинова је раније, наступајући на конгресу Друге интернационале у Паризу 1889. године, изложила програм женског социјалистичког покрета у коме је нагласила нераскидиву везу између жен-

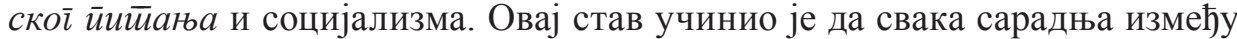
социјалисткиња и „буржоаског феминизма” буде неприхватљива из класних разлога. Дакле, у првом случају радило се о организацијама које су стремиле сарадњи с најразличитијим женским групацијама. То их је одвајало од социјалистичких група. Често је цео међународни женски покрет означаван као „буржоаски” и „европоцентричан” јер су њиме доминирале Англоамериканке и Европљанке. ${ }^{8}$ Разлике и несарадња између њих и социјалисткиња готово су избрисане после Првог светског рата у појединим државама, посебно у оним у којима жене још нису стекле грађанска и политичка права. ${ }^{9}$

${ }^{4}$ L. Rupp, V. Taylor, "Forging Feminist Identity in an International Movement”, 368; Politics and Friendship, 9.

5 Опширније у: Ана Столић, „Између национализма и интернационализма. Српкиње на конгресима организација међународног женског покрета до Првог светског рата", Истиоријски часойис LXVII (2018), 310-316.

6 Politics and Friendship, 7-8.

7 Marija Perković, „Feminizam i pacifizam”, Neko je rekao feminizam, uredila Adrijana Zaharijević, Centar za ženske studije, Rekonstrukcija ženski fond, Beograd 2012, 308-310.

8 Позната историчарка међународног женског покрета Лејла Руп, прихватајући ова означавања, наводи да је посао историчара да разуме зашто је тако било и да сагледа последице које проистичу из тога. Leila J. Rupp, Worlds of Women. The Making of an International Women's Movement, Princeton UP, Princeton 1997, 5.

9 Jelena Petrović, „Društveno političke paradigme prvog talasa jugoslovenskih feminizama”, y: Jugoslovenski feminizmi, ur. Jelena Petrović, Damir Arsenijević, Pro Femina, leto/jesen 2, specijalni broj (2011), 64. 


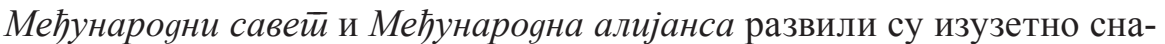
жну агитацију међу различитим женским удружењима. Освојен је медијски простор у многим земљама, покренут је велики број листова и часописа. ${ }^{10}$ Водеће представнице покрета биле су свесне историјске важности свог рада, писале су и објављивале књиге о међународном феминистичком покрету и историји организација. ${ }^{11}$ Препознале су и вредност документарних извора о раду организација, чувале су их, образовале су збирке а касније и архиве. ${ }^{12}$ Амбиција да се покрету прикључе „све жене света”, без обзира на расу, класу, религијско опредељење и социјално порекло, претворена је у принцип који је уграђен у кључна документа организација. У пракси, међутим, обе организације деловале су на основу сарадње са националним комитетима у Европи, САД, Канади, Аустралији и на Новом Зеланду. Било је предвиђено да се на нивоу националних држава формирају организације састављене од постојећих женских удружења, локалних савета или уније удружења и институција. ${ }^{13}$ Сви национални комитети могли су да присуствују конференцијама и конгресима међународних организација. ${ }^{14}$

Оваква, у потпуности „национализована” структура Међунароgно̄ савет̄ $а$ и Међунароgне алијансе, која је била заснована на идеји да збир националног представљања конституише интернационално заједништво, није погодовала многим заинтересованим женским групама и удружењима у вишенационалним империјама. ${ }^{15}$ Покушаји да се прихвате другачији облици представљања нису наилазили на разумевање вођства међународних организација. Њихова искључивост проистицала је из ,доминације западног мишљења и западноцентричних категорија", односно става да само удружења на националном нивоу могу да обликују интернационалне женске организације. ${ }^{16}$ Уколико није било могуће стварање јединствене националне организације, Алијанса је прихватала представљање посредством национал-

10 L. Delap, M. DeCenzo, L. Ryan (Eds.), Feminism and the Periodical Press 1900-1918, Vol. I, Routledge, London 2006, xxx.

11 Alice Zimmern, Women's Suffrage in Many Lands, London 1909; May Wright Sewall, Genesis of the International Council of Women and the Story of its Growth, Indianopolis 1914; Elizabeth C. Stanton, The History of Women Suffrage 1900-1920, Vol. VI, New York 1922; Dr Kaethe Schirmacher, The Modern Woman's Rights Movement, New York 1912; Women Suffrage in Practice, K. Macmillan (Ed.), London 1912; E. Snowden, The Feminist Movement, London and Glasgow 1913; А. Столић, „Између национализма и интернационализма. Српкиње на конгресима организација Међународног женског покрета до Првог светског рата", 311.

12 Међународни архив женског покрета основан је у Амстердаму 1935, у САД Светски центар за женске архиве, као и бројне колекције (нпр. Алете Јакобс, Розике Швимер).

13 Национални комитети требало је да пошаљу предлог за пријем, копију оснивачког акта, правила рада и изгласане резолуције.

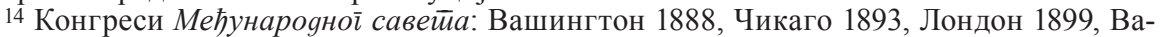
шингтон 1902, Берлин 1904, Торонто 1909, Стокхолм 1911, Рим 1914. Међунаровна алијанса одржала је конгресе у Берлину 1904, Копенхагену 1906, Амстердаму 1908, Лондону 1909 , Стокхолму 1911, Будимпешти 1913.

${ }^{15}$ Susan Zimmermann, "The Challenge of Multinational Empire for the International Women's Movement: The Habsburg Monarchy and the Development of Feminist Inter/National Politics", Journal of Women's History, Vol. 17, Number 2, Summer (2005), 89. Доступно на: http:// muse.jhu.edu/journals/jowh/summary/v017/17.2zimmermann.html. Приступљено: 24. 3. 2014.

16 Women's Activism. Global Perspectives from the 1890s to the Present, Edited by Francisca de Haan, Margaret Allen, June Purvis and Krassimira Daskalova, Routledge, New York 2013, 5. 
них комитета или почасних сарадника и сарадница. Уставом из 1904. године није прецизно одређено да ли више националних организација из једне земље може да се прикључи раду Алијансе. Приликом његове ревизије 1909. године дата је предност једној уједињеној организацији из сваке земље. Остала удружења могла су само да се придруже јединственој признатој организацији. Ово је изазвало недоумице и тензије међу женским организацијама у Централној и Источној Европи, посебно у Аустроугарској због њеног асиметричног државног система, али и у рубним деловима Руског и Немачког царства. На другој страни, пропаганда интернационализма пружила је историјску прилику која се не пропушта многим женским ненемачким и неаустријским националним организацијама на тлу Хабзбуршке монархије. ${ }^{17}$ Осим политичких питања у Монархији, међународни женски покрет требало је да се одреди и према политичким променама у међународним односима: независност Норвешке од Шведске 1905. године, промена статуса Финске од 1906. године до Октобарске револуције, као и ваневропским питањима.

Отвореност организација међународног покрета за све жене света без обзира на политичке, класне, расне и верске разлике, била је основа на којој је негован политички идеал међународног сестиринсйва. На њему се посебно инсистирало у званичној реторици на конференцијама и конгресима, извештајима о раду и оно је постављено као нешто неупитно од стране вођства

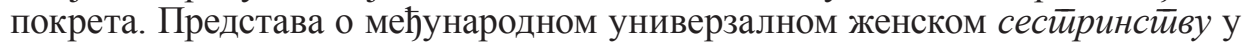
оквиру Међунарояне алијансе за йраво іласа жена грађена је на идејама о јединству у потчињености свих жена и истоветности њихових интереса. ${ }^{18}$ Пи-

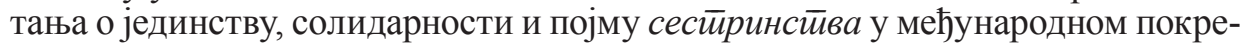
ту важна су за стицање увида о политици и општем „духу” који је владао у покрету, хијерархији која је успостављена, али и о позицији појединих националних женских удружења на међународној сцени. Она су зато значајна и за

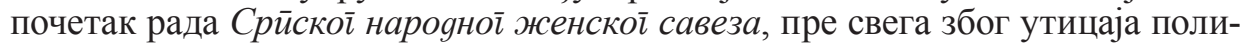
тичких идеја покрета и искустава које су његове представнице стицале у контактима са чланицама међународних организација. У првој деценији постојања међународних женских организација успостављене су везе и изграђена је специфична комуникациона мрежа помоћу које је остваривана сарадња, грађена су пријатељства и осећање солидарности за један број његових представница. Већ поменути идеал сестиринсйва тада је имао привлачну снагу и требало је да послужи као везивни елемент. Према неким анализама у првом таласу организовања женског међународног покрета конструисан је посебан колективни међународни идентитет који је „обликован не само у ширем институционалном и политичком контексту, него и борбама унутар покрета у циљу дефинисања и изражавања заједничких интереса жена". ${ }^{19}$ На другој

${ }^{17}$ Исто, 93. Међунарояни савеш̄ је пред конгрес у Лондону 1899. уложио велики напор да се на тлу Хабзбуршке монархије оснује заједнички Аустријски савет, који би укључио све делове државе и Угарску. Међу представницама других народа изван немачко-аустријског круга ова идеја није приваћена. Коначно, 1902. створен је Савез жена Аусйрије, у којем су, осим једне словеначке и пољске организације, била немачка и аустријска удружења. Исто, 95-96.

18 Politics and Friendship, 23-35.

19 Л. Руп и В. Тејлор тврдиле су да концепт колективног идентитета омогућава разумевање феминизма као политичког идентитета који се непрекидно преговара и допуњује. 
страни, преиспитивање значаја и ограничења појма сестиринстиво у историји женског покрета кроз анализу неформалних контаката, пре свега приватне преписке коју су водиле представнице вођства обе организације, омогућило је нове увиде у њихову идеологију и политичку праксу. Уочено је да су тензије између концепта „универзалног сестринства” и стварних разлика међу припадницама покрета које су потицале из различитих култура, класа, peлигија и нација заузимале централно место у раду организација. Дакле, циљ анализе преписке није био да се осветли међународно сестиринсииво „какво је оно било", него како је доживљавано или како је конструисано. ${ }^{20}$

Уобличавање колективног интернационалног духа у две међународне организације није значило да је у њиховим вођствима постојала пуна сагласност о многим стратешким питањима покрета, али ни у позиционирању према појединачним националним питањима. Постојала је веома јасна хијерархија у вођству и националним саветима из земаља чланица организација, а она није потицала из организационе структуре, него је била ,предодређена" друштвеном, класном, етничком и верском припадношћу чланица, која се није могла прикрити бројним културним праксама. У организацијама међународног женског покрета доминирале су представнице друштвених елита протестантског порекла из западноевропских друштава и САД. На тај начин репродуковани су глобални односи моћи у свету. Ограничења за оне који не припадају том друштвеном и културном кругу била су условљена природом међународног организовања, али и „непризнатом претпоставком о супериорности и природном вођству европских и америчког друштва."21 Вођство Алијансе, па и његова председница Кери Чампан Кет, сматрало је себе „напреднијим” од жена из других делова света (незападних, непротестанткиња). ${ }^{22}$ Присуство на конференцијама и конгресима и учешће у раду различитих тела организација подразумевало је предузимање дугих и скупих путовања. Њих су могле да приуште жене у зрелијим годинама које су имале сопствена средства или национални и међународни углед помоћу кога су могле да привуку донације. Некима од њих управо је новац који поседују омогућио да се вину високо у руководствима међународних организација, а у неким случајевима су пријатељи, патрони или националне организације пружали финансијску подршку. Извесно је да без обезбеђења средстава жене нису могле да учествују на сцени међународног покрета, као и да је амерички новац имао кључну улогу у функционисању организација. Осим финансија, језик је такође могао да представља баријеру, јер су у употреби били енглески, француски и немачки. Често се дешавало да представнице

Forging Feminist Identity in an International Movement, 365. На другој страни, бел хукс (bell hooks) критиковала је осамдесетих година прошлог века универзални идентитет жена који је ипак само ограничен на беле жене, домаћице, припаднице средње класе с високим образовањем, што искључује све остале које нису беле коже, које су сиромашне, без прилике да се образују. Ово је била појава доминантна у феминистичком дискурсу због расизма, класне припадности, сексизма и шовинизма његових представница. „, bel huks”, Feministickka teorija: od margine ka centru, „Feministička 94, Beograd” 2006, 11 (prev. M. Minić).

20 Politics and Friendship, 21-23.

${ }^{21}$ L. Rupp, "Constructing Internationalism: The Case of Transnational Women's Organizations 1888-1945", American Historical Review, XCIX (5) (December 1994), 1577.

22 Women's Activism. Global Perspectives from the 1890s to the Present, 3. 
различитих земаља владају добро само једним од ових језика па нису биле у могућности да прате саопштења на остала два. Представнице националних комитета из земаља са других континената доживљавале су праксу организовања конгреса, конференција и састанака искључиво у Западној и Северној Европи као дискриминаторску. Предлози да се сусрети уприличе у Аустралији или Јужној Америци, па чак и у Шпанији или на Балкану изазивали су буру негодовања у руководствима покрета. ${ }^{23}$ Даље, пропагирана верска толеранција имала је своје наличје. Иако су и у руководствима и у чланству организација биле и Јеврејке, католкиње, жене православне вероисповести и неколико муслиманки, протестански тон је преовладавао. Састанци и конференције почињале су јавном молитвом, а у календару догађаја вођство се оријентисало према верским празницима, пре свега Божићу и Ускрсу.

Пре оснивања Срйско̄̄ нарояної женскоі̄ савеза у Кнежевини/Краљевини постојала је вишедеценијска традиција женског организовања. Реч је о хуманитарним женским удружењима представница вишег друштвеног слоја у земљи. ${ }^{24}$ Осим Јеврејскоі женскоі gрущийва основаног 1874. године, Женско ярущйво у Београду је од 1875. године до почетка Првог светског рата било институција која је у организационом и финансијском смислу, по обиму активности и резултатима рада представљала „својеврстан феномен у српском друштву и на Балкану”. ${ }^{25}$ Појава нових удружења, Друщитвва „Кнеіиња Љубииа" (1899) и Кола срйских сестиара (1903), означила је промену парадигме женског хуманитарног организовања, јер су деловала у складу с патриотским родним нормативом о дужностима и задацима жена пред почетак епохе ратова. ${ }^{26}$ Осим ових удружења, у саставу Срйской народноі женскоі савеза били су Майеринско удружење и неколико подружница женских друштава у унутрашњости земље. Иако ниједна од организација које су ушле у састав Савеза није имала у свом програму феминистичке захтеве, у њима је током година зачета клица будуће еманципаторске свести. ${ }^{27}$

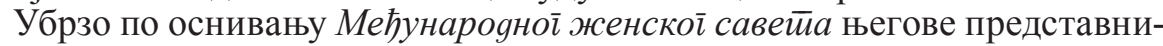
це упутиле су позивна писма за приступање организацији на бројне приватне адресе у европским и азијским земљама. Тада је учињен и први покушај да се жене у Србији прикључе међународном покрету. У писму Еме Ларан, секре-

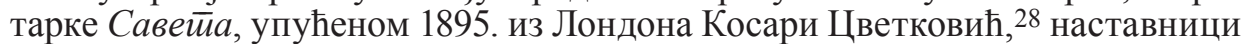
Више женске школе у Београду, био је предлог о оснивању јединственог савета Српкиња који би се прикључио међународној организацији жена. Цветковићева је наставила међународну преписку, али је сматрала да не постоје услови за оснивање националног удружења и сарадњу са међународним

${ }^{23}$ L. Rupp, "Constructing Internationalism: The Case of Transnational Women's Organizations $1888-1945$ ", 1579.

${ }^{24}$ А. Столић, Сесйре Срйкиње. Појава йокрейа за еманцийацију жена и феминизма у Краљевини Србији, Еволута, Београд 2015, 138.

${ }^{25}$ Исто, $115-116$.

${ }^{26}$ Исто, $145-154$.

27 Исто, 117.

28 Косара Цветковић (1867-1953), наставница географије и уметности у Вишој женској школи у Београду. Бавила се преводилаштвом, илустровањем и међу првима писала дечју прозу. Ауторка је монографије Вища женска щикола у Беоїраgу, Пеgесейоїодищъьияа (1913) и бројних чланака, есеја и песама. Започела је преписку с међународним женским покретом. 
покретом. Можда због тога писмо није објављено у часопису Домаћица, него га је Цветковићева проследила Аркадију Варађанину, уреднику новосадског

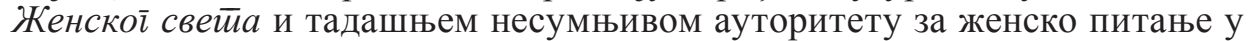
српској заједници у јужној Угарској. Занимљиво је да је у писму Варађанину изразила и жаљење што се „васкрсла утемељена вредноћа српске жене неће чути по свету". 29 Десетак година касније идеја да ће прикључивање Савеза међународним организацијама бити прилика да се Српкиње и њихова постигнућа представе на међународној сцени, заузела је важно место у аргументацији заговорница приступања покрету, али и истицања захтева за право гласа жена. Варађанин није објавио писмо јер је био уверен да идеја не би била добро прихваћена. ${ }^{30}$

У пролеће 1899. године, када се појавио роман Доле оружје Берте фон Сутнер (Bertha von Suttner) ${ }^{31}$, организовано је потписивање петиције за подршку мировној конференцији у Хагу. Позив Женском gрущишву да се придружи овој акцији стигао је из Минхена. Управа га је радо прихватила и послала је телеграм подршке конференцији, чији су текст, као и текст резолуције српских жена, написале Милка Вуловић 32 и Љубица Луковић ${ }^{33}$. Петицију је потписало преко милион жена, а ово је уједно било и прво појављивање Женской gрущйва на међународној сцени и учешће у некој међународној женској акцији. ${ }^{34}$ Нови позив уследио је годину дана пред оснивачки конгрес Међунарояне алијансе за йраво іласа жена у Берлину 1904. године. Био је упућен Женском gрущйиву које није послало своје представнице на скуп, али је цео догађај у Берлину најављен и испраћен на страницама Домаћище. Ауторка текста била је највероватније Олга Гавриловић, чланица Литерарног одбора часописа, која је навела и да је на међународној сцени уведен нов појам - женско йийање, нагласивши да је оно постало „назив за женски покрет”. 35 Почетком XX века приметна је и интензивнија комуникација с добротворним задругама Српкиња у Аустроугарској. Савка Суботић ${ }^{36}$ је 1905 . године изнела предлог да Женско gрущишво буде иницијатор уједињења свих националних друштава са обе стране Саве и Дунава у јединствену организацију. ${ }^{37}$ Београд-

29 Јелена Лазаревић, „Српски народни женски савез и Међународни женски савез”, Домаћииа, бр. 12 (1906), 358.

30 Исто; Neda Božinović, Žensko pitanje u Srbiji u 19. i 20. veku, Devedesetčetvrta, Beograd 1996, 77; Gordana Stojaković, "Women's World (1886-1914): Serbian Women's Laboratory as an Entrance into the Public Sphere", Serbian Studies, XXV, 1 (2011), 50.

31 У преводу Катарине Миловук објављен је на српском језику 1900. године.

32 Милка Вуловић (1853-1920), секретар Женской gрущйвва, основала је Друщйво „Кне-

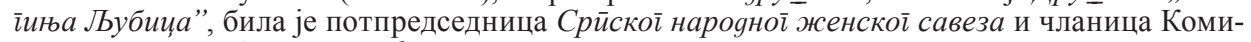

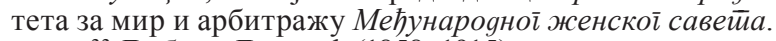

33 Љубица Луковић (1858-1915), учитељица, преводилац, болничарка у време балканских и Првог светског рата, председница Кола српских сестара. Умрла је од тифуса у болници у Нишу.

34 Јасмина Милановић, Женско ярущйво 1875-1942. (рукопис студије).

35 Исто.

36 О Савки Суботић видети: Bibliografija knjiga ženskih pisaca и Jugoslaviji, Udruženje univerzitetski obrazovanih žena u Jugoslaviji, Beograd-Ljubljana-Zagreb 1936; Gordana Stojaković, Znamenite žene Novog Sada, Futura publikacije, Novi Sad 2001; Савка Суботић, Усйомене, приредила Ана Столић, Српска књижевна задруга, Београд 2001; Гордана Стојаковић, Савка Суботиић (1834-1918). Жена која није нищйа йрећуйала, Академска књига, Нови Сад 2018.

37 Домаћица, април 1905, 123. 
ско женско друштво организовало је конференцију у Београду 1905. године, на којој су учествовале представнице већине српских женских организација из Србије и суседне Аустроугарске (Задруге Српкиња из Новог Сада, Земуна, Панчева, Сомбора, Осијека и Загреба). То је била прва женска конференција у „целом српству”. 38

Стратегија упорног и борбеног рада на придобијању нових чланица за организације међународног покрета, посебно за новоосновану Међунарояну алијансу, уродила је плодом у првој деценији XX века. У већини европских држава основани су национални савези у којима су биле окупљене женске организације и удружења. ${ }^{39}$ Они су се потом прикључивали организацијама међународног женског покрета. На Балкану је најпре у Бугарској основана Буг̆арска женска унија 1901. године, у циљу интелектуалног и духовног унапређења жена. Повод за удруживање жена била су ограничења за универзитетско образовање Бугарки деведесетих годиина XIX века. Унија је окупила око двадесет седам локалних женских друштава и предводила ју је списатељица Ана Карима. Социјалисткиње су је напустиле 1903. године, тако да је у њој наредних година преовладавао дух „традиционалних хуманитарних организација из времена националног препорода". ${ }^{40}$ Одговарајући на агитацију Међунарояне алијансе, можда и после посете њихове представнице Софији, у правила Уније 1907. године унет је захтев за пуном грађанском и политичком равноправношћу жена и мушкараца и од 1908. године ова организација прикључила се међународном женском покрету. Национални савет у Грчкој основан је 1908. године и убрзо се повезао с међународним организацијама. ${ }^{41}$

Посета Јелене Лазаревић Паризу у мају 1906. године представљала је увод у оснивање савеза у Србији. Као изасланица Женской друщйва на изложби женске радиности, на којој су излагани и предмети израђени у Раденичкој школи друштва, ступила је у везу са уредништвом женског листа Entente, у коме је отворена посебна рубрика за женско питање у Србији. Први чланак о Женском gрущиивву и његовим установама послала је пре пута у Француску. ${ }^{42}$ Сада је присуствовала и састанку Филантропског одбора $\mathrm{Me}$ -

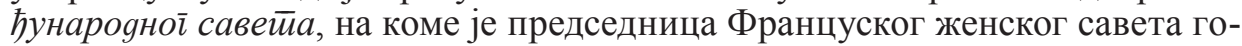
спођа Сигфрид предложила да се и у Србији оснује савез женских друшта-

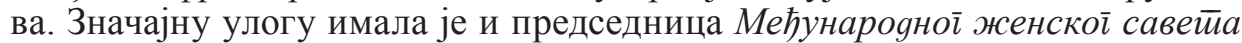
аристократкиња леди Абердин (Ishbel Maria Hamilton-Gordon, Marchioness

38 Татјана Корићанац - Љиљана Танеска, Беоіраяско женско gрущйиво 1875-1941, Музеј града Београда, Београд 1995, 34.

39 У Немачкој 1897, Француској 1899-1901, Норвешкој 1896, Шведској 1903, Чешкој 1897. и 1905, Аустрији 1902, Угарској (Мађарској) 1904.

40 Подаци о години оснивања Уније су опречни. Док се у историјама међународног покрета наводи 1899. година (нпр. Dr Kaethe Schirmacher, The Modern Women's Rights Movement, London 1912, 240) у савременој историографији се помиње 1901. година. Крассимира Даскалова, „Жоржета Назърска”, Женское gвижение и феминизми б Бълїариа (средата на 19-средата на 20. век). Women's Movement and Feminisms in Bulgaria (1850s-1950s), Бъгарска асоциация на универзитетските жени, София 2006, 12.

${ }^{41}$ Women in Changing World. The Dynamic Story of the International Council of Women since 1888, London 1966, 261; У Угарској је основан 1904. године, Истио, 254.

42 J. Милановић, Женско ярущйво 1875-1942. (рукопис студије). 
of Aberdeen and Temair). Лазаревићева је поднела извештај о свом боравку у Паризу Управи Женског gрущū̄ва, која је прихватила улогу покровитеља будуће организације. ${ }^{43}$ Исте године на конференцији Економске секције Алијансе у Хагу донета је одлука да Немица др Кете Ширмахер (Kaethe Schirmacher) ${ }^{44}$ обиђе Будимпешту, Београд и Софију и подстакне женска удружења на уједињење и прикључивање Међунарояној алијанси. Поводом ове посете у Београду је у септембру састављен посебан одбор који су чи-

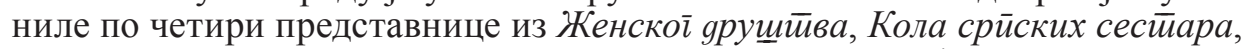

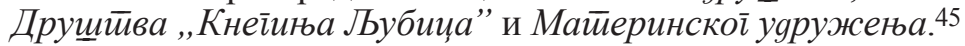

Међутим, турнеја Ширмахерове није била у потпуности остварена. Проблеми су настали у вези с њеном посетом Будимпешти. На једној у низу европских турнеја планирано је да председница и потпредседница $А л и-$ јансе Кери Чампан Кет и Алете Јакобс (Aletta Jacobs) ${ }^{46}$ одрже предавање и у главном граду Угарске. Позвале су и Кете Ширмахер да им се придружи због говорничких способности и могућности да одржи предавање на немачком језику. Испоставило се да Вилма Гликлих (Vilma Glüklih), која je ca Розом Швимер (Róza Schwimmer) предводила женски покрет у Угарској, није желела да угости Ширмахерову. Пружајући отпор покушајима из Беча да се створи јединствена женска организација у Монархији, у Будимпешти нису били расположени према немачким предавачицама, посебно не према Ширмахеровој. Известили су да се она не залаже за универзално женско право, него да је заступница варијанте ограничених политичких права жена. Био ово изговор или не, немачка активисткиња није била угошћена у угарској престоници. ${ }^{47}$ Предавање које су Кет и Јакобс одржале у препуној сали будимпештанске Касине било је, према извештавању свих већих новина, прави друштвени догађај. 48

43 Јелена Лазаревић, Енйлескиње у срйском нароgу, Београд 1929, 89.

44 Др Кете Ширмахер (1865-1930), рођена је у Данцигу (Пруска). Студирала је на Сорбони и докторирала филозофију на универзитету у Цириху. Била је једна је од водећих представница међународног женског покрета 90-их година XIX века. Активна у Међунароgном

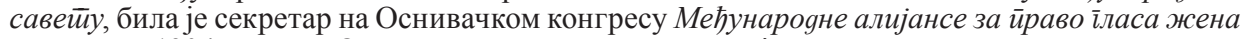
у Берлину 1904. године. Од тада почиње да инсистира у јавним наступима на национализму и политичким ставовима конзервативне деснице. Позната је по радикалним феминистичким ставовима. Крајем прве деценије XX века због екстремних националистичких германофилских ставова удаљава се од међународног женског покрета. Ауторка је књиге The Modern Women's Movement (London 1912) и бројних текстова у француској и немачкој штампи.

45 Из Майеринско̄ удружеюь то су биле: др Љубица Гођевац, др Марија Зиболд, Мица Павловић и Агница Срећковић. У: Ј. Милановић, Женско ярущишво (рукопис студије).

46 Алета Јакобс (1854-1929) била је уз Кери Чампан Кет била једна од водећих личности сифражетског и женског мировног покрета. Потиче из грађанске породице јеврејског порекла. Завршила је студије медицине 1879. и била прва жена лекар у Холандији. По завршетку студија укључила се у феминистички покрет.

47 C. C. Cat to A. Jacobs, 4. september 1906. Papers Aletta Henriëtte Jacobs, inv.no. 53, Collection International Archives for the Women's Movement (IAV), in Atria, Institute on Gender Equality and Women's History, Nederland. Доступно на: http://cdn.atria.nl/archive/pdf/IAV_ 00000081/IAV_00000081_0053.pdf. Приступљено 12. 11. 2017.

48 Papers Aletta Henriëtte Jacobs, Collection International Archives for the Women's Movement (IAV), in Atria, Institute on Gender Equality and Women's History, Nederland. Album with cuttings, a photograph and reports concerning the visit of Jacobs and Catt. English and Hungarian. 1906. Доступно на: http://cdn.atria.nl/archive/pdf/IAV_00000081/IAV_00000081_0421.pdf. 
Непосредно пред долазак Кете Ширмахер у Београд, на предлог Јелене Лазаревић основан је 5. октобра 1906. године Срйски нарояни женски савез. У вези са овим чином остаје недоумица да ли је журба да се створи организација заиста била подстакнута страхом да Ширмахерова долази у Србију с намером да, осим предавања, „оснује једну женску лигу која би радила на добијању женског права гласа", како је наведено неколико година касније. 49 Свако женско удружење одредило је по четири представнице да дочекају и приме гошћу из Немачке..$^{50}$ Ширмахерова се у својству чланице Комитета за пријем у Међународну алијансу сусрела с њима и оне су је обавестиле о оснивању Савеза. Упознала се са околностима у којима су деловала женска удружења у земљи и „разумела је одмах да Србија није земља где би женскиње требало да траже право гласа а да не изгледа смешно."51 Зато и није истрајавала на пропагирању ове идеје. Одржала је предавање о еманципацији жена у сали Београдског универзитета 12. октобра 1906. године. Одзив публике није био велик, предавање је одржано на немачком и француском језику. Било је пре свега намењено придобијању младих жена са универзитета за феминистичке идеје. Ипак, Ширмахерова није током обраћања београдској публици агитовала за политичка права жена, иако је била њихова поборница. Највише је говорила о настанку феминистичког покрета, тешкој ситуацији због тога што је рад жена недопустиво потцењен у процесу индустријализације, о занимањима која су још увек недоступна образованим женама и, коначно, о заслугама српског народа у „вишевековној заштити европске цивилизације" о чему, како је навела, до доласка у Србију није знала ништа. 52 Јавно је и упутила позив да новоосновано женско удружење приступи Међунароgној алијанси и да се његове чланице представе на следећем конгресу ове организације у Лондону 1909. године.

Анализирајући рецепцију ових догађаја у српској средини уочљиво је да су они прошли незапажено, јер о њима у дневној штампи и периодичним публикацијама није било пуно вести. У јавности ни вишедеценијска активност Женской gрущūus социјалне политике, хуманитарни ангажман жена, финансијска стабилност и економски успех његових установа нису били повод да савременици овом феномену посвете пажњу. Маргинализација њиховог рада била је очигледна, jep се о томе није пуно писало и говорило. Понекад је деловало као да су и саме жене свој ангажман доживљавале као продужетак њихових „приватних" задатака, а тек је каткада водећим чланицама хуманитарних и патриотских удружења засметало ћутање у јавности о њиховом раду. 53 Занимљиво је да непосредни утисци о Ширмахеровој и њеном предавању нису били

49 Д. Иванић, „О Српском народном женском савету и његовим задацима”, Домаћииа, 1 (1912), 10.

${ }^{50}$ Из Майеринскої уgружења: Мица Павловић, др Марија Зиболд, др Љубица Гођевац, Агница Срећковић. У: Jasmina Milanović, „Materinsko udruženje. Humani i socijalni aspekti delovanja 1904-1941", Istorija 20. veka, 2 (2018), 45.

51 Д. Иванић, „Предавање др Кети Ширмахер и наше женске прилике”, Домаћииа, 12 (1906), 359.

52 Д. Иванић, „Предавање др Кети Ширмахер”, 360.

53 На годишњем главном скупу Женской gрущūвва 1912. године критикована је незаинтересованост представника штампе за извештавање са скупа и постављено је питање 
негативни. Тако је Делфа Иванић ${ }^{54}$ ценила њене јасне пропруске германофилске ставове због којих је ова била крајње неомиљена у другим срединама. Слично као у Будимпешти, предавање јој је отказано у Познању и још неким деловима Пољске. Присећајући се боравка гошће из Немачке у Београду, Иванићева је неколико година касније навела да њено предавање није било привлачно, јер је Ширмахерова поновила „грешку својствену Германцима да када опште с другим нацијама говоре стално с једне извесне висине". 55

Ови догађаји били су повод за непосредно сагледавање и прву озбиљнију анализу положаја жена у јавном дискурсу у Србији, одмеравање и поређење са еманципацијом у европским земљама и за обазриво дефинисање најважнијих питања у вези с којима ће се неколико година касније формулисати и женски политички захтеви. ${ }^{56}$ Тада је истакнуто да је представа о еманципованим женама са запада и феминисткињама, која је била сведена на слику „чудовишта, с прљавим и аљкавим оделом, кратке косе, с цигаром у зубима, неуљудног држања", послужила противницима феминизма у већини земаља. Објашњење због чега је овај модел ,руске студенткиње” превазиђен, а да у Србији никада није ни био актуелан, послужило је ауторки текста, Делфи Иванић, као добар увод за именовање главних тачака у којима се огледа неравноправан положај жена у земљи. Разматрајући да ли у Србији постоје услови за феминизам, она је изнела неколико тема које су биле део агенде савременог међународног покрета, али су у извесном смислу представљале и преобликоване захтеве који су четири деценије раније поставиле Драга Дејановић ${ }^{57}$ и први српски социјалисти. Реч је о праву жена на рад и зараду (чиме би се спречило да питања мираза и удаје девојака буду за њих егзистенцијална) и изједначавању положаја и зарада мушкараца и жена у државној служби; о неправедним одредбама Закона о наслеђивању за женску децу, Закона о својини, односно о праву жена да располаже својом имовином у браку, Закона о утврђивању очинства. Стицање политичких права није било приоритет, али су наведена питања била подлога на којој ће се развијати, пажљиво и с више аргумената, политика и деловање Савеза у будућности. 58 Занимљиво је да у скицирању правца рада у будућности нису посебно истакнути културни и национални задаци. Они су касније, не само из стратешких разлога, стављени у први план међу циљеве

суштинске видљивости рада Друщш̄ва и његових великих заслуга у Србији. У: А. Столић, Сесйре Срйкиње, 127.

54 J. Милановић, Делфа Иванић. Заборављене усйомене, Еволута, Београд 2015, 6-84.

55 Д. Иванић, „Предавање др Кети Ширмахер”, 362; Иста, „О Српском народном женском савезу и његовим задацима”, Домаћица, бр. 12, 1906, 15; Bogna Lorence-Kot and Adam Winiarz, "The Polish women's Movement to 1914", Women's Emancipation Movements in the Nineteeth Century: A European Perspective, eds. S. Paletschek, B. Pietrow-Ennker, Stanford UP, Stanford 2004, 216.

56 Ј. Лазаревић, „Српски народни женски савез и Међународни женски савез”, 296; Д. Иванић, „О Српском народном женском савезу и његовим задацима”, 17-21.

57 Драга Дејановић (Стара Кањижа, 1840 - Стари Бечеј, 1871), школовала се у Темишвару и Пешти. Учествовала је у раду Ујеgињене омлаgине срйске. Била је глумица, учитељица, прва српска феминисткиња. Ауторка је важних текстова о положају жена у гласилима Омлаяине.

58 Д. Иванић, „Предавање др Кети Ширмахер”, 361-366. 
рада Савеза, послати су на одобрење и добили су потврду државе 1909. године. ${ }^{59}$ Прва председница Савеза била је Савка Суботић, која је убрзо постала почасна председница. На њено место изабрана је Катарина Миловук ${ }^{60}$, а потпредседнице су биле Делфа Иванић и Милка Вуловић.

Мисија др Кете Ширмахер у октобру 1906. године имала је кључну улогу у оснивању Срйской нароgноі женской савеза, коме су приступила по-

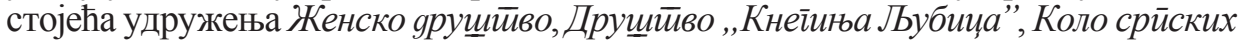
сестиара, Майеринско удружење и Јеврејско женско ярущииво. Предавање које је одржала на Београдском универзитету било је прво јавно предавање у Србији о женском покрету у свету, циљевима еманципације жена и о феминизму. Иако све до почетка 1909. године нису забележене веће активности у Савезу, водеће представнице радиле су у међувремену на уобличавању правца рада, циљева и захтева за промену положаја жена у државној служби, измену чланова Српског грађанског законика о наслеђивању женске деце, пословној способности удатих жена и положају ванбрачно рођене деце и њихових мајки. Савез се укључио у рад Међунарояне алијансе на конгресу у Лондону 1909. године и Међунаровноі савешиа на конгресу у Стокхолму 1911. године.

ORIGINAL SCIENTIFIC PAPER

Dr. ANA STOLIĆ, Senior Research Associate

The Institute of History Belgrade

Kneza Mihaila 36/II, Belgrade, Serbia

E-mail: ana.stolic@iib.ac.rs

\section{THE INTERNATIONAL CONTEXT OF THE ESTABLISHMENT OF THE SERBIAN NATIONAL WOMEN'S UNION IN 1906}

SUMMARY: The paper analyses the influence of international feminist organisations - specifically the International Council of Women and the International Woman Suffrage Alliance - on the establishment of the Serbian National Women's Union. Those were powerful organisations, attracting, through strong agitation, national associations in Europe, the US, and Australia as new members during the first decade of the $20^{\text {th }}$ century to abolish the unequal private-legal, economic, social, and political position of women and men. The mission of dr Käthe Schirmacher who, as a representative of the International Alliance, held a series of lectures in the Balkan capitals, including Belgrade in 1906, encouraged the establishment of the Serbian National Women's Union, and the re-examination of the position of women in the Kingdom of Serbia. The lecture that Schirmacher held at the Belgrade University was the first public lecture in Serbia about the women's movement in the world, the aims of the emancipation of women, and feminism. The Union was joined by the existing humanitarian women's associations - the Women's Society, Princess Ljubica Society, Circle of Serbian Sisters, Motherhood Society, and the Society of Jewish Women. Although until 1909 the Union did not carry out any major activities, its leading female representatives worked, in the meantime, on

59 А. Столић, „Правила Српског народног женског савеза из 1909. године”, Мещиовит̄ ipaちa (Miscellanea), XL (2019), 157-169.

60 О Катарини Миловук видети: Љиљана Станков, Кайарина Миловук и женски ӣокрей y Србији, Педагошки музеј, Београд 2011. 
defining the course of its work, objectives, and requirements. They dealt with changing the position of women in the state services, amending articles of the Serbian Civil Code which pertained to the inheritance of female children, the business capacity of married women, and the position of children born out of wedlock and their mothers. The Union joined the International Alliance at the congress held in London in 1909, and the International Women's Council at the congress held in Stockholm in 1911.

KEYWORDS: Serbian National Women's Union, International Woman Suffrage Alliance, International Women's Council, sisterhood, feminism 